Article

\title{
Gut Bacterial Communities in Geographically Distant Populations of Farmed Sea Bream (Sparus aurata) and Sea Bass (Dicentrarchus labrax)
}

\author{
Eleni Nikouli ${ }^{1}$ (i), Alexandra Meziti ${ }^{1}$, Efthimia Antonopoulou ${ }^{2}$, Eleni Mente ${ }^{1 \text { (1) }}$ and \\ Konstantinos A. Kormas ${ }^{1, *}$ iD \\ 1 Department of Ichthyology and Aquatic Environment, School of Agricultural Sciences, \\ University of Thessaly, Volos 384 46, Greece; nikouli.eleni@gmail.com (E.N.); ameziti@gmail.com (A.M.); \\ emente@uth.gr (E.M.) \\ 2 Laboratory of Animal Physiology, Department of Zoology, School of Biology, Aristotle \\ University of Thessaloniki, Thessaloniki 541 24, Greece; eantono@bio.auth.gr \\ * Correspondence: kkormas@uth.gr; Tel.: +30-242-109-3082
}

Received: 18 July 2018; Accepted: 31 August 2018; Published: 1 September 2018

\begin{abstract}
This study investigated the profile of the autochthonous gut bacterial communities in adult individuals of Sparus aurata and Dicentrarchus labrax reared in sea cages in five distantly located aquaculture farms in Greece and determine the impact of geographic location on them in order to detect the core gut microbiota of these commercially important fish species. Data analyses resulted in no significant geographic impact in the gut microbial communities within the two host species, while strong similarities between them were also present. Our survey revealed the existence of a core gut microbiota within and between the two host species independent of diet and geographic location consisting of the Delftia, Pseudomonas, Pelomonas, Propionibacterium, and Atopostipes genera.
\end{abstract}

Keywords: teleosts; intestine; bacteria; microbiota; aquaculture

\section{Introduction}

Studies on fish gastrointestinal tract microbiota (GITM) are mostly focused on the isolation, identification and evaluation of microorganisms in farmed species. The main target of such studies is the possible use of these microorganisms as potential probiotics in order to promote fish growth and health [1]. With the advent of next generation sequencing technologies, results have demonstrated that fish GITM diversity shows higher complexity than originally considered [2]. Knowing the core microbiota (sensu [3]) is pivotal in predicting and further investigating the provided microbial services to the host [4], since these communities are important for the ecological understanding of the gut habitat and the functions of its microbes [5]. The investigation of co-occurrence patterns, including core and less frequent occurring microbes, has been shown to be extremely useful for depicting fundamental and keystone microbial species across same types of habitats-host in spatial and temporal scales [6]. Such approaches have shown that correlations between microbes and latitude can exist even for the human gut [7].

While dietary studies profiling the human gut microbiota pose certain limitations [8], sea cage farmed fish species can be a good model system to investigate fish core GITM since these populations are genetically homogeneous and consume a well-balanced diet that meets their nutritional requirements throughout their life cycle, while populations of the same species are reared in similar environmental conditions. For fish GITM, it has been suggested that these communities are not mere reflections of their host's habitat but are rather shaped by host-specific selective forces [9]. In this study, we compared the GITM of Sparus aurata and Dicentrarchus labrax individuals originating from five 
distantly located aquaculture installations in Greece in order to reveal their core GITM, i.e., bacteria that occur across all samples regardless of location and supplied diet.

\section{Materials and Methods}

Adult individuals of $S$. aurata and D. labrax, weighing on average $451 \pm 86.4$ and $481.3 \pm 165.5$ (Table S1), respectively, were collected from five commercial aquaculture farms distantly located from each other in different areas in Greece (Figure S1). Fish were grown in sea cages and fed commercial diets (Table S2), and raised under similar husbandry conditions (temperature, $\mathrm{pH}$, salinity, feeding frequency) throughout the rearing cycle. All samples were collected in September 2014 in order to limit possible seasonal variations. Fish were sacrificed by emersion on ice water, packaged in insulated boxes with melted ice $\left(0^{\circ} \mathrm{C}\right)$, and transferred to the laboratory within $6-24 \mathrm{~h}$. Wet weight was measured and gut tissues were obtained by aseptic dissection and the intestinal content was squeezed out. The midgut from 4-6 individuals from each species $(n=2)$ originating from the same cage in every location $(n=5)$ was excised with sterile scissors and rinsed with sterile particle free seawater, as we targeted the resident gut microorganisms, i.e., epi and endobionts of the gut tissue cells, and not the ones associated with the ingested food. Gut samples were kept at $-80{ }^{\circ} \mathrm{C}$ until further analysis. DNA was extracted directly from ca. $0.25 \mathrm{~g}$ gut tissue using the PowerMax Soil DNA Isolation kit (MoBio, Carlsbad, CA, USA) according to manufacturer's protocol. The concentrations of extracted DNA (absorbance at 260nm) and purity (absorbance ratio 260/280) were measured using NanoDrop (ThermoScientific, Waltham, MA, USA). We analyzed the 16S rDNA gene diversity of gut bacteria from each individual sample, targeting the $\mathrm{V} 3 \neg \mathrm{V} 4$ region by using 454 pyrosequencing with the primer pair $S \neg D$-Bact $\neg 0341 \neg b \neg S \neg 17$ and $S \neg D \neg$ Bact $\neg 0785 \neg a \neg A \neg 21$ [10]. Samples were sequenced utilizing Roche 454 FLX titanium instruments and reagents after following manufacturer's guidelines at the MRDNA Ltd. (Shallowater, TX, USA) sequencing facilities. Pyrosequencing reads were processed by the MOTHUR platform (Pat Schloss, University of Michigan, MI, USA; version 1.38) [11,12]. Only sequences with $\geq 250 \mathrm{bp}$ and no ambiguous or no homopolymers $\geq 8$ bp were considered for further analysis. All remaining sequences were binned in operational taxonomic units (OTUs) and were clustered using a 97\% sequence similarity threshold. OTUs taxonomic classification was determined by the SILVA Incremental Aligner (SINA) online alignment service for small (16S) subunit ribosomal RNA [13], by setting minimum identity with query sequence 0.95 and by rejecting sequences below identity $80 \%$. The sequences that could not be classified into any known phylum were assigned as "unclassified" from the SILVA database, release 130 [14].

Statistical analysis and graphical illustrations were performed using the PAlaeontological STudies (PAST) software [15] and the R Studio platform [16]. Macroecological patterns were calculated based on species area relationship (SAR) according to [17]. To evaluate host-specific dynamics, we applied the "DOC method" [18] by calculating the correlation between the overlap and dissimilarity of all OTUs for all the possible individual pairs from the five locations for each host species. To reveal microbial associations within the gut environment the network approach of [19] was used based on the ratio of positive to total correlations of the most dominant OTUs in individuals of S. aurata and D. labrax. Raw sequence data from this study have been submitted to the Sequence Read Archive (https:/ / www.ncbi.nlm.nih.gov/sra/) with accession numbers SRR5161931 and SRR5803847, for S. aurata and D. labrax, respectively.

\section{Results and Discussion}

In this study, we analyzed the midgut bacterial diversity of farmed Sparus aurata and Dicentrarchus labrax individuals in order to determine members of the adult core microbiota of these commercially important fish species. Taking into account that microbiota are important in health and disease, revealing the core microbiota of a species would be important in order to explore how to achieve a beneficial collaboration between host and microbiota (for a review see [5]). The analyzed fish individuals had the following features: (a) common genetic origin, (b) very similar supplied commercial 
feed (Table S2), (c) origin from distant aquaculture farms (23-554 km between them), (d) similar age, and (e) were sampled within days. These criteria allowed us to assess the core microbiota of these animals by minimizing the effects of host genetics, nutritional state and environmental stressors (e.g., salinity, temperature) variability. In this study, core OTUs refer to the ones found in each individual midgut sample. The effect of the surrounding water was not studied since it is expected to be insignificant for the GITM diversity as shown previously [20-23]. A single water sampling on the same day of the midgut sampling of the investigated fish individuals, would not be so informative due to the following two factors: 1) marine bacterioplankton is characterized by strong variation in short (e.g., [24,25]) and longer [26-29] time scales, and 2) the life cycle of farmed S. aurata and D. labrax spans over several months. To the best of our knowledge, this is the first study combining all the above features for the gut bacterial communities of S. aurata and D. labrax. Floris et al. [30] investigated the gut microbiota of $S$. aurata at two coastal lagoons in Sardinia, Italy, but their study was based on older techniques with limited power to uncover the full extent of biodiversity. For D. labrax, there are a few relevant studies but were mainly focused on candidate probiotic's evaluation [31-34] and the effect of alternative feed ingredients in gut microbiome [35].

Despite the low reads numbers in some samples (Table 1) rarefaction curves have reached a plateau (Figure S2), indicating satisfactory coverage of the existing bacterial OTUs. The effect of different aquaculture location on bacterial species richness was not important since OTUs richness between locations did not vary significantly (Figure S3). Each species had a rather defined bacterial community, with $10-21$ OTUs accounting for $\geq 80 \%$ of the relative abundance per sample (Table 1).

All detected OTUs belonged to 11 different phyla (Figure S4), commonly occurring in fish gut [36,37] with Proteobacteria, Firmicutes, Actinobacteria dominating $(>78 \%)$ across all samples. Bacteroidetes-related OTUs also occurred in all locations for both species but with lower contributions (Figure S4). The rest of the phyla (Chloroflexi, Spirochaetae, Deinoccocus-Thermus, Cyanobacteria, Saccharibacteria, Gemmatimonadetes, Actinobacteria) occurred sporadically in low abundances $(\leq 1.5 \%)$.

Within Proteobacteria in S. aurata, Betaproteobacteria was the dominant class in four locations (Yaltra, Chania, Chios, Igoumenitsa; Greece), while in Atalanti, Betaproteobacteria and Gammaproteobacteria co-dominated, with $22.1 \%$ and $23.7 \%$, respectively (Figure S4). Other than this, Gammaproteobacteria was the second most abundant class of Proteobacteria, with Alphaproteobacteria always in low abundances (Figure S4). On the contrary, in D. labrax, Gammaproteobacteria dominated in three locations (Chania, Yaltra, Atalanti; Greece) followed by Betaproteobacteria and Alphaproteobacteria. In the rest of the locations (Igoumenitsa and Chios; Greece), Betaproteobacteria was the dominant taxon. In general, Alphaproteobacteria abundances in D. labrax were higher than in S. aurata (Figure S4). The most abundant orders in all locations for both host species were the Micrococcales, Corynebacteriales, Propionibacteriales, Bifidobacteriales, Flavobacteriales, Bacteroidales, Bacillales, Lactobacillales, Burkholderiales and Pseudomonadales.

A small set of OTUs was found to occur in all individuals from all five locations (8 in S. aurata and 10 in D. labrax), i.e., representing the core mid gut microbiota (sensu [3]) for each species (Figure 1). Moreover, five of these OTUs (Figure 1) were shared between the two species. The closest phylogenetic relatives for these OTUs were Delftia acidovorans (Burkholderiales), Pseudomonas panacis (Pseudomonadales), Pelomonas puraquae (Burkholderiales), Propionibacterium acnes (Propionibacteriales) and Atopostipes suicloacalis (Lactobacillales). (Table S3). The estimation of the shared OTUs doubling time (based on the 16S rDNA gene copy number [38] ranged between 0.8 and $2.0 \mathrm{~h}^{-1}$ (Table S3), implying that they represent bacteria which can grow fast in the fish GIT and thus, they are more likely to outcompete other bacterial taxa. 
Table 1. Pyrosequencing results of the bacterial 16S rDNA gene diversity in the midgut of Sparus aurata and Dicentrarchus labrax individuals (N) from different aquaculture sites in Greece. OTUs: operational taxonomic units; N: number of individual midgut samples analyzed.

\begin{tabular}{|c|c|c|c|c|c|c|c|c|}
\hline \multirow[t]{2}{*}{ Site } & \multicolumn{2}{|c|}{ Reads } & \multicolumn{2}{|c|}{ OTUs } & \multicolumn{2}{|c|}{$\begin{array}{l}\text { No. of the Most Dominant OTUs } \\
\text { (Cumulative Relative Dominance } \geq 80 \% \text { ) }\end{array}$} & \multicolumn{2}{|c|}{$\begin{array}{l}\text { Most Abundant OTU, Dominance (\%) } \\
\text { and Closest Relative }(\geq 97 \%)\end{array}$} \\
\hline & S. aurata & D. labrax & S. aurata & D. labrax & S. aurata & D. labrax & S. aurata & D. labrax \\
\hline Chania & $\begin{array}{l}827 \pm 512.4 \\
\quad N=4\end{array}$ & $\begin{array}{c}2395 \pm 725.4 \\
N=5\end{array}$ & $11 \pm 2.2$ & $16 \pm 8.7$ & $10(80.0)$ & 17 (79.9) & $\begin{array}{l}\text { OTU0011 (22.7) } \\
\text { Micrococcus luteus }\end{array}$ & $\begin{array}{c}\text { OTU0014 (17.2) } \\
\text { Paracocccus denitrificans }\end{array}$ \\
\hline Igoumenitsa & $\begin{array}{c}2360 \pm 1972.7 \\
N=5\end{array}$ & $\begin{array}{c}1809 \pm 571.3 \\
N=4\end{array}$ & $25 \pm 28.3$ & $27 \pm 20.3$ & $13(81.0)$ & $14(80.0)$ & $\begin{array}{l}\text { OTU0004 (27.8) } \\
\text { Bacillus hisashii }\end{array}$ & $\begin{array}{l}\text { OTU0001 (19.9) } \\
\text { Corynebacterium vitaeruminis }\end{array}$ \\
\hline Chios & $\begin{array}{c}2407 \pm 1771.0 \\
N=6\end{array}$ & $\begin{array}{c}2148 \pm 1785.2 \\
N=6\end{array}$ & $18 \pm 11.4$ & $17 \pm 9.8$ & 13 (79.5) & 13 (80.9) & $\begin{array}{l}\text { OTU0004 (22.0) } \\
\text { Bacillus hisashii }\end{array}$ & $\begin{array}{l}\text { OTU0001 (24.7) } \\
\text { Corynebacterium vitaeruminis }\end{array}$ \\
\hline Yaltra & $\begin{array}{c}2656 \pm 1529.0 \\
N=6\end{array}$ & $\begin{array}{c}697 \pm 367.3 \\
N=6\end{array}$ & $19 \pm 12.2$ & $11 \pm 2.4$ & $21(80.0)$ & $10(79.9)$ & $\begin{array}{l}\text { OTU0002 (16.9) } \\
\text { Delftia acidovorans }\end{array}$ & $\begin{array}{l}\text { OTU0025 (21.9) } \\
\text { Acinetobacter lwoffii }\end{array}$ \\
\hline Atalanti & $\begin{array}{c}1574 \pm 1005.9 \\
N=4\end{array}$ & $\begin{array}{c}2533 \pm 1052.7 \\
N=5\end{array}$ & $13 \pm 6.1$ & $14 \pm 8.1$ & $12(80.1)$ & $11(80.0)$ & $\begin{array}{c}\text { OTU0005 (14.7) } \\
\text { Pseudomonas extremaustralis }\end{array}$ & $\begin{array}{l}\text { OTU0002 (17.7) } \\
\text { Delftia acidovorans }\end{array}$ \\
\hline
\end{tabular}


S. aurata

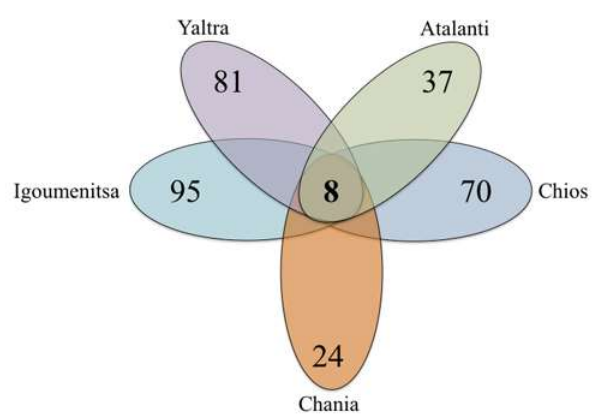

D. labrax

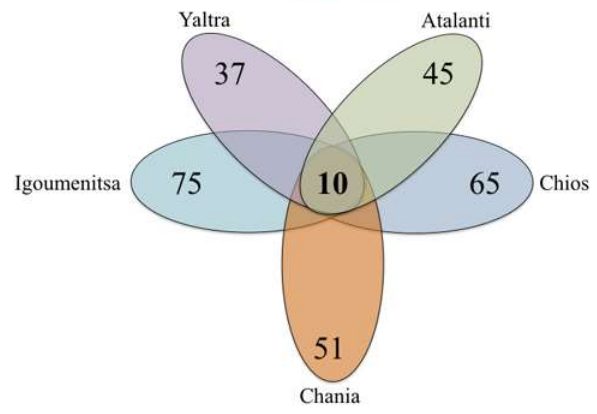

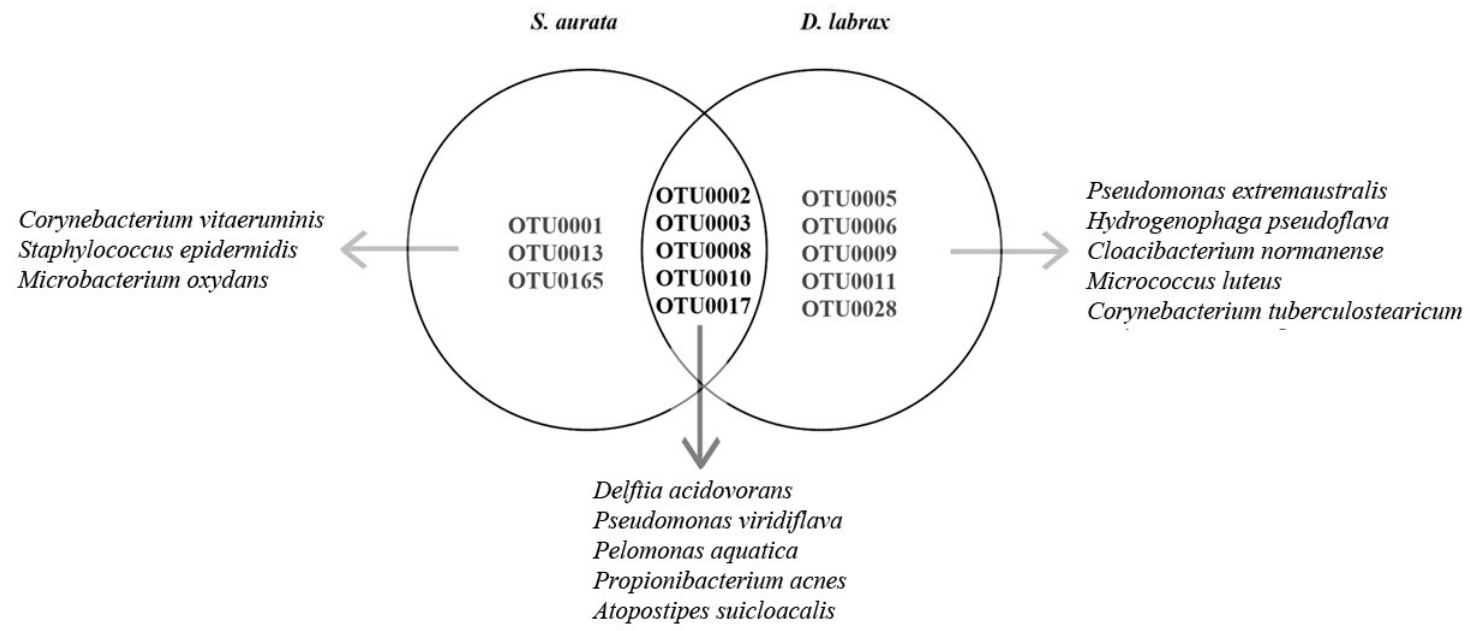

Figure 1. Flower diagram of the shared operational taxonomic units (OTU) between Sparus aurata and Dicentrarchus labrax individuals from different aquaculture sites in Greece.

Delftia spp. have been previously retrieved from fish gut of healthy grouper [39], rainbow trout [40], 2012), and Atlantic salmon [41] individuals. The members of this genus are strictly aerobic and chemo-organotrophic but not fermentative [42]. Pseudomonas spp. have been isolated from several fish species and have been evaluated as potential probiotics in aquaculture industry [43-45]. Pelomonas sp. could be a resident GITM as it has been found in the gut of farmed fish [46]. Propionibacterium acnes is commonly found in fish [21,47-50] and snails [51] but its major importance for the human skin microbiome [52] renders it as an uncertain autochthonous gut symbiont for S. aurata and D. labrax. Atopostipes is a fermentative genus and to date it has been associated with fermented flesh of skate (Raja pulchra) [53] but also with the Atlantic salmon (Salmo salar) gut [49]. Thus, it is likely a bacterium with potential fermentative role in farmed S. aurata and D. labrax.

S. aurata shared OTUs belonged to taxa (Burkholderiales, Pseudomonadales, Flavobacteriales, Actinobacteria) reported in wild, organic and conventionally reared S. aurata individuals [48] while the identified closest relatives of these OTUs have been previously retrieved from similar environments (Table S3). This further suggests that these bacteria could be members of $S$. aurata core bacterial community.

The observed core bacterial community for both species consisted mostly from nonsporulating, mesophilic bacteria, with diverse types of respiration with some of them presenting important features in other animals. For example, Micrococcus luteus possesses anti-Vibrio activity in the freshwater fish Oreochromis niloticus; Pseudomonas panacis degrades cellulose in the gut of the bark beetles Dendroctonus armandi, while $P$. veronii has been reported to have metabolic pathways related to central carbohydrate metabolism, nutrients uptake and plant hormone auxin production in the grapevine, Vitis vinifera, root [54]. Most of the rest core gut bacterial OTUs, in S. aurata and D. labrax were assigned to similar orders such as Corynebacteriales, Pseudomonadales and Micrococcales, though in different species 
(Table S2). Most of them have been retrieved from similar isolation sources (e.g., stool, intestine, manure) (Table S3). The number of OTUs occurring only in one location varied between 11-61 and 22-55 for S. aurata and D. labrax, respectively (Figure S4).

Geographic distance between the aquaculture farms did not show any correlation with the gut bacterial community structure for both species (Figure S5) and nonmetric multidimensional scaling (NMDS, Figure S6) based on the Bray-Curtis distance of presence/absence OTUs, showed no clear geographic separation (ANOSIM using Euclidean distances $p=0.391, R=9.3^{-5}$ ) of the gut bacterial communities for both species as well. This implies, that the observed GITM structure for each of the two fish species investigated in this study are not related to the vicinity of the aquaculture farms.

In the current study, the correlations between the overlap and dissimilarity of GITM communities structure were positive for both fish species considered $(r=0.477$ and 0.574 for $p<0.002$ in S. aurata and D. labrax, respectively) (Figure 2), suggesting high inter-individual variability in terms of OTUs abundances even in the same location. Similar results have also been observed in fecal microbiota for both S. aurata and D. labrax [55,56]. While in human gut microbiome, the inter-individual variability is more easily understood due to parameters such as dietary patterns and personal interests $[57,58]$, here we concluded that inter-individual variability in the autochthonous gut bacteria of D. labrax and S. aurata, is more likely related with individual genetic factors. The observed inter-individual variability means that the gut microenvironment of these two host fish species promotes selective pressure in the bacterial communities. However, while the overlap of these bacterial communities increases, the same happens with dissimilarity, indicating host-independent parameters also shaping gut bacterial community in human [18,59] and fish GITM [60,61].

The most prominent factors promoting the inter-individual microbiota variation have only recently been taken into account and these are host genotype, gut colonization during the early developmental stages, environmental effects on GITM acquisition, diet, diseases and respective medication [8]. One reason for the GITM inter-individual variability is that caged fish are fed mechanically, a way that does not secure equal food consumption for each fish due to individual differences in their activity. The extent of GITM individual variability is important to know for the following reasons: (a) it dictates the number of replicate samples per species that need to be analyzed [58], (b) it helps distinguishing between autochthonous (resident) bacteria which colonize the gut mucosa and the allochthonous (transient) bacteria occurring mostly in the digesta $[9,62]$. The demonstrated individual host variability could be the reason for the low number of shared OTUs in both allopatric populations studied here, but larger datasets are required in order to fully unravel this issue. 


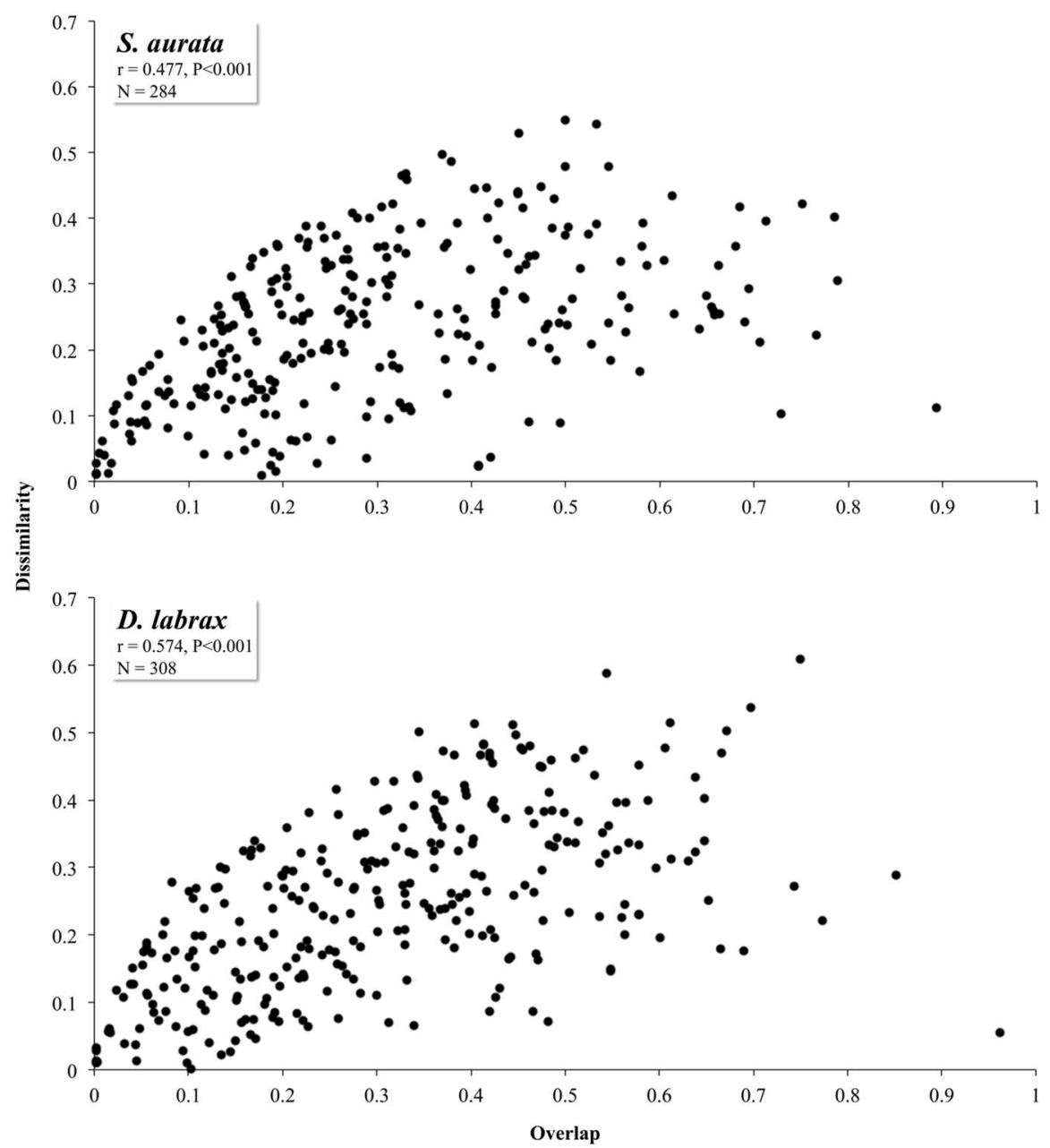

Figure 2. Dissimilarity vs. overlap correlation of all the possible sample pairs of the gut bacterial operational taxonomic units between different Sparus aurata and Dicentrarchus labrax aquaculture sites in Greece.

Although one-way analysis of variance (ANOVA) revealed no statistically significant differences between gut bacterial communities for both species $(p>0.05)$, (Figure S3), the biological relations of the bacterial communities were different. The ratio of positive to total (PT) correlations of the most dominant OTUs of $S$. aurata and D. labrax individuals was significantly different $(p<0.05)$, suggesting different biological relationships in the guts of the two species (Figure 3). The high ratio of the positive to total (PT) correlations of the most dominant operational taxonomic units demonstrates that the majority of the dominant bacteria have either cooperative interactions or, at least, they do not participate in competitive nutrition. Such relationships in microbial populations are believed to be beneficial to the host as they ensure high capacity of utilizing the complex array of available substrates found in the gut $[35,63,64]$. 


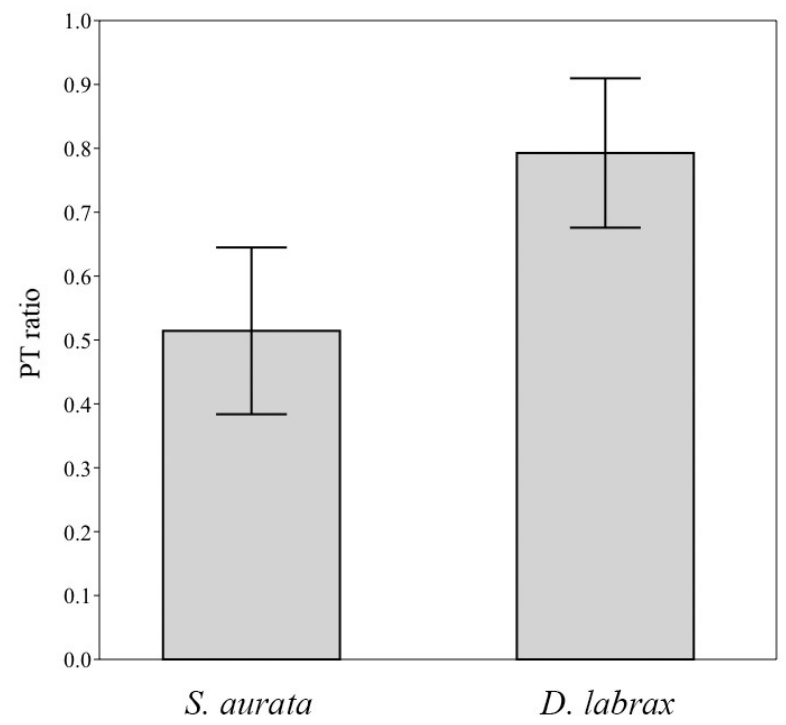

Figure 3. Ratio of positive to total (PT) correlations (Pearson, $-0.7>R>0.7, p<0.05$ ) of the most dominant operational taxonomic units (OTUs) in Sparus aurata and Dicentrarchus labrax individuals from aquaculture sites in Greece. Vertical lines indicate standard error.

\section{Conclusions}

It is still unknown whether and how the gut microbial communities of fish can contribute nutrients and energy to the host and maintain a balance with the fish's metabolism and immune system. This study presents evidence for core gut bacterial communities within the two examined host species (S. aurata and D. labrax), and also a small set of OTUs that have been found in common between them, indicating that some autochthonous gut bacterial representatives of the Delftia, Pseudomonas, Pelomonas, Propionibacterium and Atopostipes genera can colonize different host species. Despite the inter-individual variability and the distance of each farm location, there is no significant difference between the gut bacterial communities in the two host species. The results also revealed these gut bacterial communities form different biological relations between their members as revealed by their populations association networks.

Supplementary Materials: The following are available online at http:/ /www.mdpi.com/2076-2607/6/3/92/s1, Table S1. Body weight of the Sparus aurata and Dicentrarchus labrax individuals used in this study; Table S2. Ingredients of the diets used at the time of sampling; Table S3. Bacterial 16S rDNA operational taxonomic units (OTU) found in the midgut of commercially reared Sparus aurata and Dicentrarchus labrax individuals from different aquaculture sites in Greece; Figure S1. Aquaculture sampling sites. I: Igoumenitsa, Y, Yaltra, A: Atalanti, Ch: Chios, C: Chania; Figure S2. Rarefaction curves bacterial operational taxonomic units generated by16S rDNA tag pyrosequencing from the midgut of Sparus aurata and Dicentrarchus labrax individuals originating from different aquaculture farms in Greece; Figure S3. Box-plot of the bacterial operational taxonomic units found in the midgut of Sparus aurata and Dicentrarchus labrax individuals originating from different aquaculture farms in Greece; Figure S4. Taxonomy (phyla: top row; Proteobacteria sub-phyla: bottom row) of the found bacterial operational taxonomic units found in the midgut of Sparus aurata and Dicentrarchus labrax individuals originating from different aquaculture farms in Greece; Figure S5. Relationship of the shared operational taxonomic units (OTUs) and the total number of OTUs with the distance between different Sparus aurata and Dicentrarchus labrax aquaculture sites in Greece; Figure S6. Non-metric multidimensional scaling (NMDS) based on the gut bacterial operational taxonomic units between Sparus aurata and Dicentrarchus labrax individuals from different aquaculture sites in Greece. Red and blue lines include all S. aurata and D. labrax samples, respectively.

Author Contributions: E.N.: performed field and laboratory analyses, analyzed the data, and contributed to paper writing; A.M.: analyzed the data and contributed to paper writing; E.A.: conceived the study and contributed to paper writing; E.M.: conceived the study and contributed to paper writing; K.A.K: conceived the study, analyzed the data, and wrote the first draft of the paper.

Acknowledgments: We thank the Nireus and Zervas-Kyriazis aquaculture companies in Greece for providing the fish samples.

Conflicts of Interest: The authors declare no conflicts of interest. 


\section{References}

1. Hai, N.V. The use of probiotics in aquaculture. J. Appl. Microbiol. 2015, 119, 917-935. [CrossRef] [PubMed]

2. Sullam, K.E.; Essinger, S.D.; Lozupone, C.A.; O'Connor, M.P.; Rosen, G.L.; Knight, R.O.B.; Kilham, S.S.; Russell, J.A. Environmental and ecological factors that shape the gut bacterial communities of fish: A meta-analysis. Mol. Ecol. 2012, 21, 3363-3378. [CrossRef] [PubMed]

3. Hamady, M.; Knight, R. Microbial community profiling for human microbiome projects: Tools, techniques, and challenges. Genome Res. 2009, 19, 1141-1152. [CrossRef] [PubMed]

4. Llewellyn, M.S.; Boutin, S.; Hoseinifar, S.H.; Derome, N. Teleost microbiomes: The state of the art in their characterization, manipulation and importance in aquaculture and fisheries. Front. Microbiol. 2014, 5, 1-17. [CrossRef] [PubMed]

5. Shade, A.; Handelsman, J. Beyond the venn diagram: The hunt for a core microbiome. Environ. Microbiol. 2012, 14, 4-12. [CrossRef] [PubMed]

6. Zelezniak, A.; Andrejev, S.; Ponomarova, O.; Mende, D.R.; Bork, P.; Patil, K.R. Metabolic dependencies drive species co-occurrence in diverse microbial communities. Proc. Natl. Acad. Sci. USA 2015, 112, 6449-6454. [CrossRef] [PubMed]

7. Suzuki, T.A.; Worobey, M. Geographical variation of human gut microbial composition. Biol. Lett. 2014, 10, 20131037. [CrossRef] [PubMed]

8. Flint, H.J.; Duncan, S.H.; Louis, P. The impact of nutrition on intestinal bacterial communities. Curr. Opin. Microbiol. 2017, 38, 59-65. [CrossRef] [PubMed]

9. Wong, S.; Rawls, J.F. Intestinal microbiota composition in fishes is influenced by host ecology and environment. Mol. Ecol. 2012, 21, 3100-3102. [CrossRef] [PubMed]

10. Klindworth, A.; Pruesse, E.; Schweer, T.; Peplies, J.R.; Quast, C.; Horn, M.; Glöckner, F.O. Evaluation of general 16s ribosomal RNA gene PCR primers for classical and next-generation sequencing-based diversity studies. Nucleic Acids Res. 2012, 41, e1. [CrossRef] [PubMed]

11. Schloss, P.D.; Gevers, D.; Westcott, S.L. Reducing the effects of PCR amplification and sequencing artifacts on 16s rRNA-based studies. PLoS ONE 2011, 6, e27310. [CrossRef] [PubMed]

12. Schloss, P.D.; Westcott, S.L.; Ryabin, T.; Hall, J.R.; Hartmann, M.; Hollister, E.B.; Lesniewski, R.A.; Oakley, B.B.; Parks, D.H.; Robinson, C.J.; et al. Introducing mothur: Open-source, platform-independent, community-supported software for describing and comparing microbial communities. Appl. Environ. Microbiol. 2009, 75, 7537-7541. [CrossRef] [PubMed]

13. Pruesse, E.; Peplies, J.; Glöckner, F.O. Sina: Accurate high-throughput multiple sequence alignment of ribosomal RNA genes. Bioinformatics 2012, 28, 1823-1829. [CrossRef] [PubMed]

14. Quast, C.; Pruesse, E.; Yilmaz, P.; Gerken, J.; Schweer, T.; Yarza, P.; Peplies, J.; Glöckner, F.O. The SILVA ribosomal RNA gene database project: Improved data processing and web-based tools. Nucleic Acids Res. 2013, 41, D590-D596. [CrossRef] [PubMed]

15. Hammer, Ø.; Harper, D.; Ryan, P. Past: Paleontological statistics software package for education and data analysis. Palaeontol Electr. 2001, 4, 1-9.

16. Team, R. Rstudio. Integrated development for R. Rstudio, Inc., Boston, MA. Available online: http://www. rstudio.com/ (accessed on 2 July 2018).

17. Lennon, J.T.; Locey, K.J. Macroecology for microbiology. Environ. Microbiol. Rep. 2017, 9, 38-40. [CrossRef] [PubMed]

18. Bashan, A.; Gibson, T.E.; Friedman, J.; Carey, V.J.; Weiss, S.T.; Hohmann, E.L.; Liu, Y.-Y. Universality of human microbial dynamics. Nature 2016, 534, 259-262. [CrossRef] [PubMed]

19. Morueta-Holme, N.; Blonder, B.; Sandel, B.; McGill, B.J.; Peet, R.K.; Ott, J.E.; Violle, C.; Enquist, B.J.; Jørgensen, P.M.; Svenning, J.-C. A network approach for inferring species associations from co-occurrence data. Ecography 2016, 39, 1139-1150. [CrossRef]

20. Meziti, A.; Mente, E.; Kormas, K.A. Gut bacteria associated with different diets in reared Nephrops norvegicus. Syst. Appl. Microbiol. 2012, 35, 473-482. [CrossRef] [PubMed]

21. Estruch, G.; Collado, M.C.; Peñaranda, D.S.; Tomás Vidal, A.; Jover Cerdá, M.; Pérez Martínez, G.; Martinez-Llorens, S. Impact of fishmeal replacement in diets for gilthead sea bream Sparus aurata on the gastrointestinal microbiota determined by pyrosequencing the 16s rRNA gene. PLoS ONE 2015, 10, e0136389. [CrossRef] [PubMed] 
22. Schmidt, V.T.; Smith, K.F.; Melvin, D.W.; Amaral-Zettler, L.A. Community assembly of a euryhaline fish microbiome during salinity acclimation. Mol. Ecol. 2015, 24, 2537-2550. [CrossRef] [PubMed]

23. Borsodi, A.K.; Szabó, A.; Krett, G.; Felföldi, T.; Specziár, A.; Boros, G. Gut content microbiota of introduced bigheaded carps (Hypophthalmichthys spp.) inhabiting the largest shallow lake in central Europe. Microbiol. Res. 2017, 195, 40-50. [CrossRef] [PubMed]

24. Ottesen, E.A.; Young, C.R.; Gifford, S.M.; Eppley, J.M.; Marin, R.; Schuster, S.C.; Scholin, C.A.; DeLong, E.F. Multispecies diel transcriptional oscillations in open ocean heterotrophic bacterial assemblages. Science 2014, 345, 207-212. [CrossRef] [PubMed]

25. Aylward, F.O.; Eppley, J.M.; Smith, J.M.; Chavez, F.P.; Scholin, C.A.; DeLong, E.F. Microbial community transcriptional networks are conserved in three domains at ocean basin scales. Proc. Natl. Acad. Sci. USA 2015, 112, 5443-5448. [CrossRef] [PubMed]

26. Fuhrman, J.; Steele, J.A. Community structure of marine bacterioplankton: Patterns, networks, and relationships to function. Aquat. Microb. Ecol. 2008, 53, 69-81. [CrossRef]

27. Meziti, A.; Kormas, K.A.; Moustaka-Gouni, M.; Karayanni, H. Spatially uniform but temporally variable bacterioplankton in a semi-enclosed coastal area. Syst. Appl. Microbiol. 2015, 38, 358-367. [CrossRef] [PubMed]

28. Bunse, C.; Pinhassi, J. Marine bacterioplankton seasonal succession dynamics. Trends Microbiol. 2017, 25, 494-505. [CrossRef] [PubMed]

29. Troussellier, M.; Escalas, A.; Bouvier, T.; Mouillot, D. Sustaining rare marine microorganisms: Macroorganisms as repositories and dispersal agents of microbial diversity. Front. Microbiol. 2017, 8, 947. [CrossRef] [PubMed]

30. Floris, R.; Manca, S.; Fois, N. Microbial ecology of intestinal tract of gilthead sea bream (Sparus aurata Linnaeus, 1758) from two coastal lagoons of Sardinia (Italy). Transit. Waters Bull. 2013, 7, 4-12. [CrossRef]

31. Silvi, S.; Nardi, M.; Sulpizio, R.; Orpianesi, C.; Caggiano, M.; Carnevali, O.; Cresci, A. Effect of the addition of Lactobacillus delbrueckii subsp. delbrueckii on the gut microbiota composition and contribution to the well-being of European sea bass (Dicentrarchus labrax, L.). Microbial Ecology in Health and Disease 2008, 20, 53-59. [CrossRef]

32. Bourouni, O.C.; El Bour, M.; Calo-Mata, P.; Mraouna, R.; Abedellatif, B.; Barros-Velàzquez, J. Phylogenetic analysis of antimicrobial lactic acid bacteria from farmed seabass Dicentrarchus labrax. Can. J. Microbiol. 2012, 58, 463-474. [CrossRef] [PubMed]

33. Lamari, F.; Mahdhi, A.; Chakroun, I.; Esteban, M.A.; Mazurais, D.; Amina, B.; Gatesoupe, F.J. Interactions between candidate probiotics and the immune and antioxidative responses of European sea bass (Dicentrarchus labrax) larvae. J. Fish Dis. 2016, 39, 1421-1432. [CrossRef] [PubMed]

34. Mladineo, I.; Bušelić, I.; Hrabar, J.; Radonić, I.; Vrbatović, A.; Jozić, S.; Trumbić, Ž. Autochthonous bacterial isolates successfully stimulate in vitro peripheral blood leukocytes of the European sea bass (Dicentrarchus labrax). Front. Microbiol. 2016, 7. [CrossRef] [PubMed]

35. Torrecillas, S.; Mompel, D.; Caballero, M.J.; Montero, D.; Merrifield, D.; Rodiles, A.; Robaina, L.; Zamorano, M.J.; Karalazos, V.; Kaushik, S.; et al. Effect of fishmeal and fish oil replacement by vegetable meals and oils on gut health of European sea bass (Dicentrarchus labrax). Aquaculture 2017, 468, 386-398. [CrossRef]

36. Givens, C.; Ransom, B.; Bano, N.; Hollibaugh, J. Comparison of the gut microbiomes of 12 bony fish and 3 shark species. Mar. Ecol. Prog. Ser. 2015, 518, 209-223. [CrossRef]

37. Tarnecki, A.M.; Burgos, F.A.; Ray, C.L.; Arias, C.R. Fish intestinal microbiome: Diversity and symbiosis unravelled by metagenomics. J. Appl. Microbiol. 2017, 123, 2-17. [CrossRef] [PubMed]

38. Roller, B.R.K.; Stoddard, S.F.; Schmidt, T.M. Exploiting rRNA operon copy number to investigate bacterial reproductive strategies. Nat. Microbiol. 2016, 1, 16160. [CrossRef] [PubMed]

39. Sun, Y.; Yang, H.; Ling, Z.; Chang, J.; Ye, J.D. Gut microbiota of fast and slow growing grouper Epinephelus coioides. Afr. J. Microbiol. Res. 2009, 3, 713-720. [CrossRef]

40. Navarrete, P.; Magne, F.; Araneda, C.; Fuentes, P.; Barros, L.; Opazo, R.; Espejo, R.; Romero, J. PCR-TTGE analysis of 16s rRNA from rainbow trout (Oncorhynchus mykiss) gut microbiota reveals host-specific communities of active bacteria. PLoS ONE 2012, 7, e31335. [CrossRef] [PubMed]

41. Gajardo, K.; Rodiles, A.; Kortner, T.M.; Krogdahl, Å.; Bakke, A.M.; Merrifield, D.L.; Sørum, H. A high-resolution map of the gut microbiota in Atlantic salmon (Salmo salar): A basis for comparative gut microbial research. Sci. Rep. 2016, 6, 30893. [CrossRef] [PubMed] 
42. Wen, A.; Fegan, M.; Hayward, C.; Chakraborty, S.; Sly, L.I. Phylogenetic relationships among members of the Comamonadaceae, and description of Delftia acidovorans (Den Dooren De Jong 1926 and Tamaoka et al. 1987) gen. nov., comb. nov. Int. J. Syst. Evol. Microbiol. 1999, 49, 567-576. [CrossRef] [PubMed]

43. Abd El-Rhman, A.M.; Khattab, Y.A.E.; Shalaby, A.M.E. Micrococcus luteus and Pseudomonas species as probiotics for promoting the growth performance and health of Nile tilapia, Oreochromis niloticus. Fish Shellfish Immunol. 2009, 27, 175-180. [CrossRef] [PubMed]

44. Korkea-aho, T.L.; Heikkinen, J.; Thompson, K.D.; von Wright, A.; Austin, B. Pseudomonas sp. M174 inhibits the fish pathogen Flavobacterium psychrophilum. J. Appl. Microbiol. 2011, 111, 266-277. [CrossRef] [PubMed]

45. Lazado, C.C.; Caipang, C.M.A.; Kiron, V. Enzymes from the gut bacteria of Atlantic cod, Gadus morhua and their influence on intestinal enzyme activity. Aquacult. Nutr. 2012, 18, 423-431. [CrossRef]

46. Rasheeda, M.K.; Rangamaran, V.R.; Srinivasan, S.; Ramaiah, S.K.; Gunasekaran, R.; Jaypal, S.; Gopal, D.; Ramalingam, K. Comparative profiling of microbial community of three economically important fishes reared in sea cages under tropical offshore environment. Mar. Genomics 2017, 34, 57-65. [CrossRef] [PubMed]

47. Carda-Diéguez, M.; Mira, A.; Fouz, B. Pyrosequencing survey of intestinal microbiota diversity in cultured sea bass (Dicentrarchus labrax) fed functional diets. FEMS Microbiol. Ecol. 2014, 87, 451-459. [CrossRef] [PubMed]

48. Kormas, K.A.; Meziti, A.; Mente, E.; Frentzos, A. Dietary differences are reflected on the gut prokaryotic community structure of wild and commercially reared sea bream (Sparus aurata). MicrobiologyOpen 2014, 3, 718-728. [CrossRef] [PubMed]

49. Godoy, F.A.; Miranda, C.D.; Wittwer, G.D.; Aranda, C.P.; Calderón, R. High variability of levels of Aliivibrio and lactic acid bacteria in the intestinal microbiota of farmed Atlantic salmon Salmo salar L. Ann. Microbiol. 2015, 65, 2343-2353. [CrossRef]

50. Rurangwa, E.; Sipkema, D.; Kals, J.; ter Veld, M.; Forlenza, M.; Bacanu, G.M.; Smidt, H.; Palstra, A.P. Impact of a novel protein meal on the gastrointestinal microbiota and the host transcriptome of larval zebrafish Danio rerio. Front. Physiol. 2015, 6. [CrossRef] [PubMed]

51. Koleva, Z.; Dedov, I.; Kizheva, J.; Lipovanska, R.; Moncheva, P.; Hristova, P. Lactic acid microflora of the gut of snail Cornu aspersum. Biotechnol. Biotechnol. Equip. 2014, 28, 627-634. [CrossRef] [PubMed]

52. Krutmann, J. Pre- and probiotics for human skin. J Dermatol. Sci. 2009, 54, 1-5. [CrossRef] [PubMed]

53. Jang, G.I.; Kim, G.; Hwang, C.Y.; Cho, B.C. Prokaryotic community composition in alkaline-fermented skate (Raja pulchra). Food Microbiol. 2017, 61, 72-82. [CrossRef] [PubMed]

54. Montes, C.; Altimira, F.; Canchignia, H.; Castro, Á.; Sánchez, E.; Miccono, M.; Tapia, E.; Sequeida, Á.; Valdés, J.; Tapia, P.; et al. A draft genome sequence of Pseudomonas veronii R4: A grapevine (Vitis vinifera L.) root-associated strain with high biocontrol potential. Stand. Genomic Sci. 2016, 11, 76. [CrossRef] [PubMed]

55. De Schryver, P.; Dierckens, K.; Bahn Thi, Q.Q.; Amalia, R.; Marzorati, M.; Bossier, P.; Boon, N.; Verstraete, W. Convergent dynamics of the juvenile European sea bass gut microbiota induced by poly- $\beta$-hydroxybutyrate. Environ. Microbiol. 2011, 13, 1042-1051. [CrossRef] [PubMed]

56. Silva, F.C.D.P.; Nicoli, J.R.; Zambonino-Infante, J.L.; Kaushik, S.; Gatesoupe, F.-J. Influence of the diet on the microbial diversity of faecal and gastrointestinal contents in gilthead sea bream (Sparus aurata) and intestinal contents in goldfish (Carassius auratus). FEMS Microbiol. Ecol. 2011, 78, 285-296. [CrossRef] [PubMed]

57. Costello, E.K.; Lauber, C.L.; Hamady, M.; Fierer, N.; Gordon, J.I.; Knight, R. Bacterial community variation in human body habitats across space and time. Science 2009, 326. [CrossRef] [PubMed]

58. Gatesoupe, F.-J.; Huelvan, C.; Le Bayon, N.; Le Delliou, H.; Madec, L.; Mouchel, O.; Quazuguel, P.; Mazurais, D.; Zambonino-Infante, J.-L. The highly variable microbiota associated to intestinal mucosa correlates with growth and hypoxia resistance of sea bass, Dicentrarchus labrax, submitted to different nutritional histories. BMC Microbiol. 2016, 16, 266. [CrossRef] [PubMed]

59. Faust, K.; Raes, J. Host-microbe interaction: Rules of the game for microbiota. Nature 2016, 534, $182-183$. [CrossRef] [PubMed]

60. Hovda, M.B.; Lunestad, B.T.; Fontanillas, R.; Rosnes, J.T. Molecular characterisation of the intestinal microbiota of farmed Atlantic salmon (Salmo salar L.). Aquaculture 2007, 272, 581-588. [CrossRef]

61. Zarkasi, K.Z.; Taylor, R.S.; Glencross, B.D.; Abell, G.C.J.; Tamplin, M.L.; Bowman, J.P. In vitro characteristics of an Atlantic salmon (Salmo salar L.) hind gut microbial community in relation to different dietary treatments. Res. Microbiol. 2017, 168, 751-759. [CrossRef] [PubMed] 
62. Sánchez, B.; Delgado, S.; Blanco-Míguez, A.; Lourenço, A.; Gueimonde, M.; Margolles, A. Probiotics, gut microbiota, and their influence on host health and disease. Mol. Nutr. Food Res. 2017, 61, 1600240. [CrossRef] [PubMed]

63. Coyte, K.Z.; Schluter, J.; Foster, K.R. The ecology of the microbiome: Networks, competition, and stability. Science 2015, 350, 663-666. [CrossRef] [PubMed]

64. Widder, S.; Allen, R.J.; Pfeiffer, T.; Curtis, T.P.; Wiuf, C.; Sloan, W.T.; Cordero, O.X.; Brown, S.P.; Momeni, B.; Shou, W.; et al. Challenges in microbial ecology: Building predictive understanding of community function and dynamics. ISME J. 2016, 10, 2557-2568. [CrossRef] [PubMed]

(c)

(C) 2018 by the authors. Licensee MDPI, Basel, Switzerland. This article is an open access article distributed under the terms and conditions of the Creative Commons Attribution (CC BY) license (http:/ / creativecommons.org/licenses/by/4.0/). 